\title{
Cell Tower Technician Dies after Antenna Array Falls and Decapitates Him
}

\section{Incident Number: 14KY032}

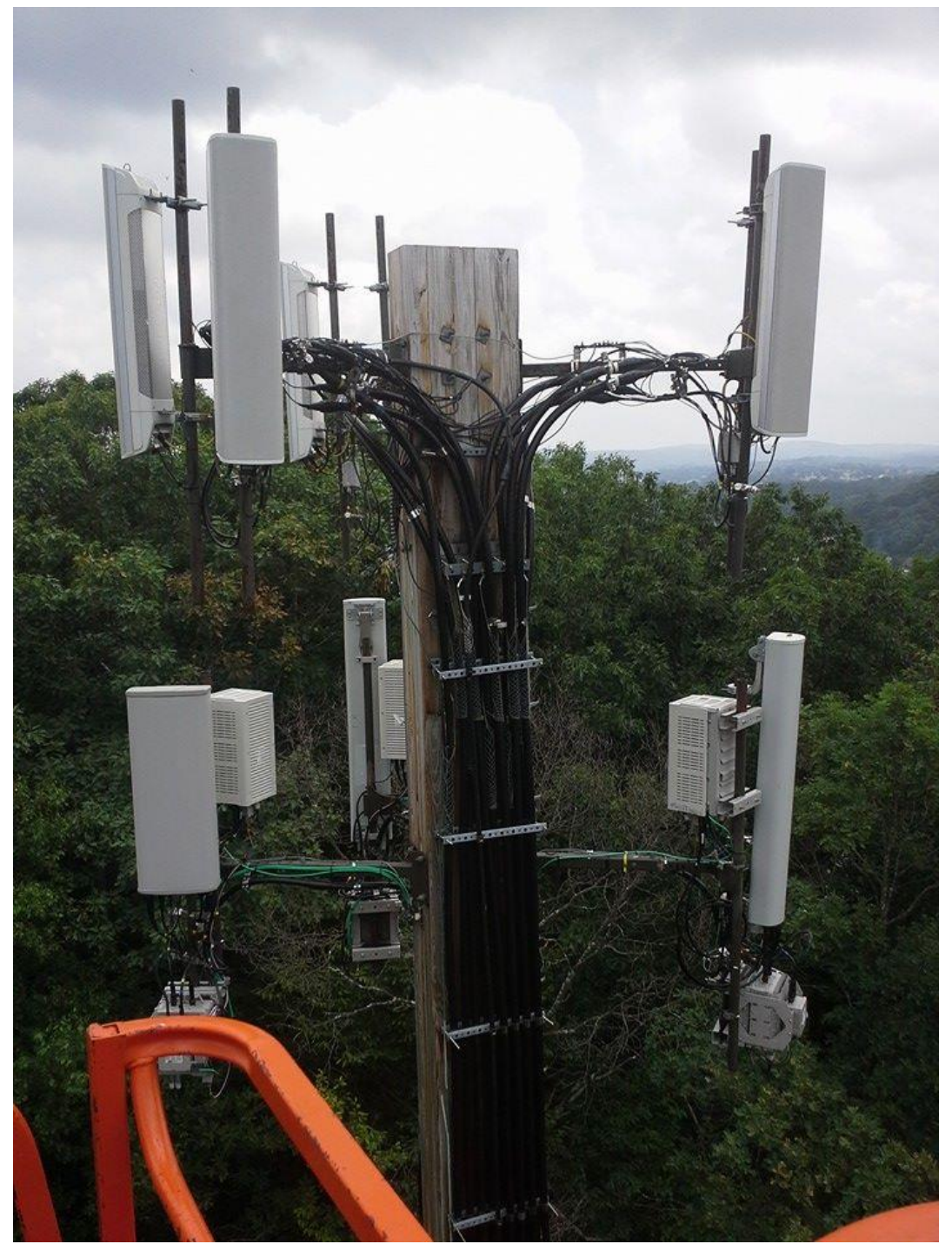

Photo courtesy of KY OSHA

Kentucky Fatality Assessment and Control Evaluation Program Kentucky Injury Prevention and Research Center 333 Waller Avenue Suite 242

Lexington, Kentucky 40504

Phone: 859-323-2981

Fax: 859-257-3909

www.kiprc.uky.edu

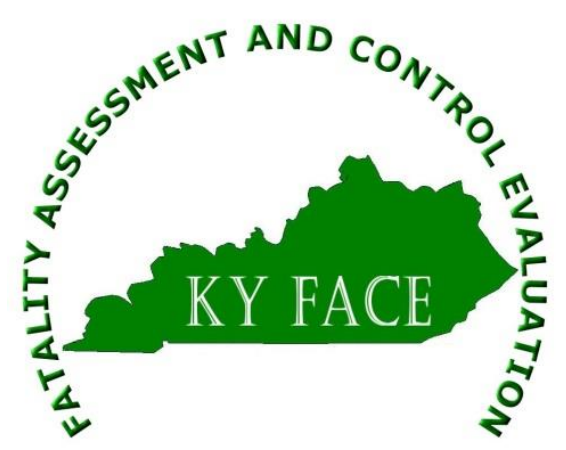




\section{Kentucky Fatality Assessment and Control Evaluation (FACE) Program \\ Incident Number: 14KY032 \\ Release Date: August 17, 2015 \\ Subject: Cell Tower Technician Dies after Antenna Array Falls and \\ Decapitates Him}

\section{Introduction}

On July 2, 2014, at approximately 2:15 pm, a 28-year-old tower technician and father of three was 242 feet in the air on a cellular tower performing maintenance. His task was to upgrade and replace 3 antenna arrays or "booms" that weighed approximately $1800 \mathrm{lbs}$. each. The victim was on the load-bearing side of the tower while another employee was on the opposite side, 25 feet below the victim. The crew had already replaced 2 of the 3 antenna arrays and was in the process of setting the third in its place, when they heard a loud pop. The antenna array was 15 feet above the victim on a McKissick "Snatch Block" pulley, Model 419. The supporting shackle suffered a catastrophic failure causing the cable to snap. The antenna array crashed down striking three points on the tower, then the cables amputated the victim's head, and right arm. The employee on the opposite side immediately radioed the ground crew and reported the victim's demise. The ground crew called 911, at 2:22 pm, to report the fatality and ask for assistance in lowering the victim to the ground. They also requested power shut-off for an energized electric line contacting the broken cables. Emergency crews arrived on the scene, minutes later, to begin the tedious process of lowering the victim to the ground.

To prevent future occurrences of similar incidents, the following recommendations have been made:

Recommendation No. 1: Employers should ensure that a competent rigger is on site to perform a site hazard assessment before work is performed.

Recommendation No. 2: Employers should ensure that all tower technicians are competent and trained on proper equipment use, procedures, and how to safely do their jobs.

Recommendation No. 3: Employers should ensure that regular inspection of required antenna replacement equipment is performed before initiating work.

Recommendation No. 4: Cell tower employers should ensure that antenna replacement equipment is used properly and according to manufacturers' recommendations.

\section{$\underline{\text { Employer }}$}

The employer was established in 2005 and located in another state. The employer provides telecommunication tower repair services to clients and operates in 14 states. The company has 64 employees. There were four employees on the job site. 


\section{Written Safety Programs and Training}

Written worker safety programs were available to employees, as well as internal safety training. The employer informed the investigator the tower technicians attended a two-day intensive class that included field training, and they received certification from Comtrain upon successful completion. Documentation provided by the employer showed two of the employees on the jobsite were basic certified in Tower Climbing Safety and Rescue. The certification showed they were certified through another company, not the employer. Documentation was also provided showing the victim was given new hire orientation, which included training in personal protective equipment, provided basic information on tie off procedures, basic understanding of the work performed by a tower technician and instruction regarding how to properly wear and use the safety equipment. There was no documentation for the fourth employee on any type of safety training. When asked during interviews if any of the four employees were certified competent riggers, the employees said two of the four were certified competent riggers through Comtrain, but no documentation was provided for verification.

Comtrain is a company located in Austin, Texas, that created Tower Safety \& Rescue Training in 1996. They provide climbing safety, fall protection and rescue training in cities throughout the United States. They were the first to develop standards for Tower Safety and Rescue Training and provide the highest level of safety training for all types of structures, occupations, and industries. Comtrain most recently, February 2015, added rigging classes to their training. Therefore, Comtrain could not have been the trainer for the two employees who stated they were certified riggers through Comtrain.

\section{$\underline{\text { Victim }}$}

The victim was a 28-year-old father of three children, who had been employed with the company for five months. His occupation was tower technician. He was a high school graduate.

\section{Cell Tower Technician}

A cell tower technician must be physically fit, enjoy climbing, and have no fear of heights. Tower technicians work at heights ranging from 200-500 feet above the ground. The physical requirements involve climbing a ladder while carrying tools and gear. Technicians work outside all year round in all weather conditions, including wind, snow, rain and extreme temperatures.

Tasks include replacing light bulbs, antennas and transmission lines. Technicians also pay close attention to the conditions of the tower to determine any structural repairs needed and take action such as tightening bolts to account for bent steel. Technicians work under pressure to meet deadlines and respond to any type of network tower outages. The ability to read blueprints and schematics is important to determine project tasks, which can include installing or upgrading antennas, installing network cabling and using electronic test equipment to inspect the tower's operation. 


\section{Incident Scene}

The scene was a fenced 10,000 square foot field with a wireless cellular telephone antenna site. The antenna site was secured with an 8-foot-high fence with two strands of barbed cable at the top and a gate with a locking mechanism. The tower was positioned on 3 concrete footers in the center of the 10,000 square foot area. The tower was 245 feet tall and self-supporting with multiple carriers.

\section{Equipment and Machinery}

Each antenna array weighs $1800 \mathrm{lbs}$. and is routinely lifted to the destination point via a winch system. In this incident, the winch controls were based at a truck on the ground level, with a steel cable that reached from the winch controls to a pivoting point over which the antenna would be placed, and then down to the antenna itself. Routinely, the cable would be fastened to the antenna by a forged alloy shackle. The employer reported using a 5/8" shackle that would have provided a working load limit of $7000 \mathrm{lbs}$. and should have easily supported and not failed. However, there was evidence gathered at the scene to suggest that a carbineer was used in place of the proper shackle. A carbineer would not have been sufficient to support the weight tension from the winch system. A carbineer is a self-closing and self-locking connecting device for personal fall arrest or positioning systems. It must have a minimum breaking strength of 5,000 lbs. and the gate must withstand 3,600 lbs. of force in all directions without deformity, to meet ANSI X259.1 manufacturer's instructions.

\section{$\underline{\text { Weather }}$}

July 2, 2014, was a partly cloudy day with temperatures ranging from 68 to 85 degrees Fahrenheit. Wind speed recorded at 1:54 pm had variable winds of $5.8 \mathrm{mph}$. Weather was not a factor in this fatality.

\section{$\underline{\text { Investigation }}$}

The Kentucky Fatality Assessment and Control Evaluation Program was notified by the Kentucky Labor Cabinet, July 2, 2014, of an occupational fatality involving a cell tower technician.

On July 2, 2014, four cell phone tower technicians reported to the tower at 7:00 am to complete a job they had begun the day before. They were contracted to replace and upgrade three antenna arrays or "booms" that weighed $1800 \mathrm{lbs}$. each. They held a pre-work meeting, inspected their equipment and checked for a common radio frequency (RF). Although no common RF was detected, the four employees donned their fall protection equipment and began their tasks.

The victim and another tower technician, who had only been on the job for 8 days, climbed the tower to replace the antenna arrays (image 1). It is not known if the 8 day tower technician had previous experience. They worked steadily and replaced two of the three antenna arrays. They began replacing the third antenna array and had it raised above the victim. The victim was on the 
load bearing side of the tower at 242 feet above the ground. The other cell tower technician was on the opposite side at 217 feet. The antenna array was 15 feet above the victim on a McKissick "snatch block" pulley, model 419. Around 2:20 pm, the crew heard a loud pop. The supporting shackle had failed and caused the cable to snap. The antenna crashed down, striking three points on the tower, then the cables decapitated the victim and amputated his right arm between the elbow and shoulder. Two cell tower employees on the ground avoided being struck by the crashing antenna (image 2). When the cell tower technician on the opposite side of the tower saw the victim hanging from his fall protection equipment, he radioed the ground crew and asked them to call 911. The employees also requested that the power be turned off at an energized electrical line in contact with the broken cables.

The 911 call was received at 2:22 pm and emergency crews (including the sheriff, EMS and fire department) arrived on the scene at 2:34 pm. They began recovering the victim, who was hanging from his fall protection harness. After assessing the situation, a technical rescue group was called to help retrieve the victim. It took over 7 hours after the technical rescue group arrived to lower the victim and transport him to the coroner's office.

Search groups including KY OSHA, the company's insurance carrier, and the sheriff's department searched for the broken shackle for four days with metal detectors, but were unable to locate it. However, a shattered carabineer was recovered at the site the day of the incident, indicating that it could have been used on the winch in place of the shackle (image 3 ). This discovery could explain why the shackle was not recovered.

\section{Cause of Death}

The cause of death was decapitation by an industrial cable.

\section{$\underline{\text { Recommendations and Discussions }}$}

\section{Recommendation No. 1: Employers should ensure that a competent rigger is on site to perform a site hazard assessment before work is performed.}

According to ANSI/TIA standard 1019-A 2.2.1, a competent rigger is a person knowledgeable and experienced with the procedures and equipment common to the communication structures industry and is trained to identify hazards with authorization to take prompt corrective measures. ${ }^{1}$ This is imperative on each job site to ensure the safety of employees involved.

There are several rigging trainers with programs to train competent riggers across the United States. They offer a 2 day basic rigging class as well as a 3 day advanced rigging class. These classes are to teach the riggers the importance of proper slings and rigging hardware selections, basic math applications, weight calculations, center of gravity determination, stress dynamics in wire rope, effects of sling angles and the inspection of the sling, rigging and hardware. Once the basic rigging is completed successfully with hands on and written testing, the rigger can then move on to achieving an advanced certification. 
The advanced rigging class will teach the rigger to select the components and procedures based on rigging capacity and perform the following tasks unsupervised. The rigger will be taught to estimate load weight and center of gravity, identify lift points, determine and select rigging based on load, perform pre-use inspection of rigging and lift points, identify and attach rigging with knowledge of the hitch configurations and load angle factor, determine rigging capacities and load integrity, understand load dynamics and associated hazards, as well as build a working knowledge of hoisting equipment, winches, jacks, industrial rollers and similar equipment. Upon completion of these courses, the competent rigger takes written and practical examinations.

By certifying employees, the employer can be assured of competent employees on the job site, reducing the risk of injury or death.

\section{Recommendation No. 2: Employers should ensure that all tower technicians are competent and trained on proper equipment use, procedures, and how to safely do their jobs.}

Basic tower climbing and safety training is essential so that rigging employees are informed of the safety measures necessary to ensure their lives. All new hires should be required to complete this training prior to beginning any work. The training should be no less than 8 hours. A written test as well as hands on demonstration of the knowledge is completed by the employee and documented by the employer to be compliant with OSHA standard 29CFR 1926. 503.

It is a common practice in this industry for climbers to frequently use carabineers for rigging. They are convenient to connect and disconnect easily. OSHA, as well as manufacturers, stress never to use personal protective equipment, rescue rope and rescue rigging for hoisting material. This equipment is only designed for personal protection, not rigging. OSHA regulation 1926.502(d) (18) states: Body belts, harnesses, and components shall be used only for employee protection (as part of a personal fall arrest system or positioning device system) and not to hoist materials. $^{2}$

\section{Recommendation No. 3: Employers should ensure that regular inspection of required antenna replacement equipment is performed before initiating work.}

Inspection of the antenna replacement equipment prior to beginning work, would allow employees to identify any defects and repair or remove the equipment to ensure safety. Creating a pre-work inspection sheet would encourage employees to follow the steps and also document the inspection. The checklist could include but not be limited to the following:

\footnotetext{
$\checkmark \quad$ Recognition of environmental hazards

$\checkmark \quad$ Recognition of job site hazards

$\checkmark \quad$ Inspection of all equipment being used

$\checkmark \quad$ Inspection of all personal protective equipment, including fall protection

$\checkmark \quad$ Review of emergency and rescue plan

$\checkmark \quad$ Evaluation of crew's physical fitness for job performance

$\checkmark \quad$ Inspection of tower and foundation
} 


\section{Recommendation No. 4: Cell tower employers should ensure that antenna replacement equipment is used properly and according to manufacturers' recommendations.}

A four day search, which included metal detectors, did not produce the required shackle. The shackle is made from forged steel alloy, a metal that is very strong with a low failure rate. The shackle was not found onsite, but a broken carabineer was discovered the day of the incident. The carbineer did not originate from the fall arrest equipment, because the fall protection remained securely intact with the victim. The carabineer may have been used in place of the shackle, and used in the wrong spot.

Employers need to stress that using the right equipment and taking the extra steps to do so keeps employees safe.

\section{$\underline{\text { Keywords }}$}

Cell tower

Cell tower industry

Cell tower workers

Worker fatality

Worker safety

Rigging

OSHA

Occupational safety

\section{References}

${ }^{1}$ Standard for Installation, Alteration and Maintenance of Antenna Supporting Structures and Antennas. Telecommunications Industry Association. Print. Published August 29, 2011.

${ }^{2} 29$ CFT 1926 Safety and Health Regulations for Construction 1926.502 (d) 18.

\section{Further Resources}

1. National Association of Tower Erectors. http://www.natehome.com/

2. Worker's at Heights Safety \& Health Initiative. http://ohccupstate.org/projects_heights.cfm

3. OSHA- Communication Towers. http://www.osha.gov/doc/topics/communicationtower/ 
Acknowledgements

The Kentucky FACE program would like to thank the Sheriff's Department, the County Fire and EMS, Kentucky OSHA, the Coroner's office, the news media and the National Association of Tower Erectors (NATE), J.P. Jones especially, and Wally Reardon, Project Coordinator at Worker's at Heights Safety \& Health Initiative for their assistance with this report.

The Kentucky Fatality Assessment \& Control Evaluation Program (FACE) is funded by grant 2U60OH008483-10 from the Centers for Disease Control and Prevention and the National Institute for Occupational Safety and Health. The purpose of FACE is to aid in the research and prevention of occupational fatalities by evaluating events leading to, during, and after a work related fatality. Recommendations are made to help employers and employees have a safer work environment. For more information about FACE and KIPRC, please visit our website: www.kiprc.uky.edu 


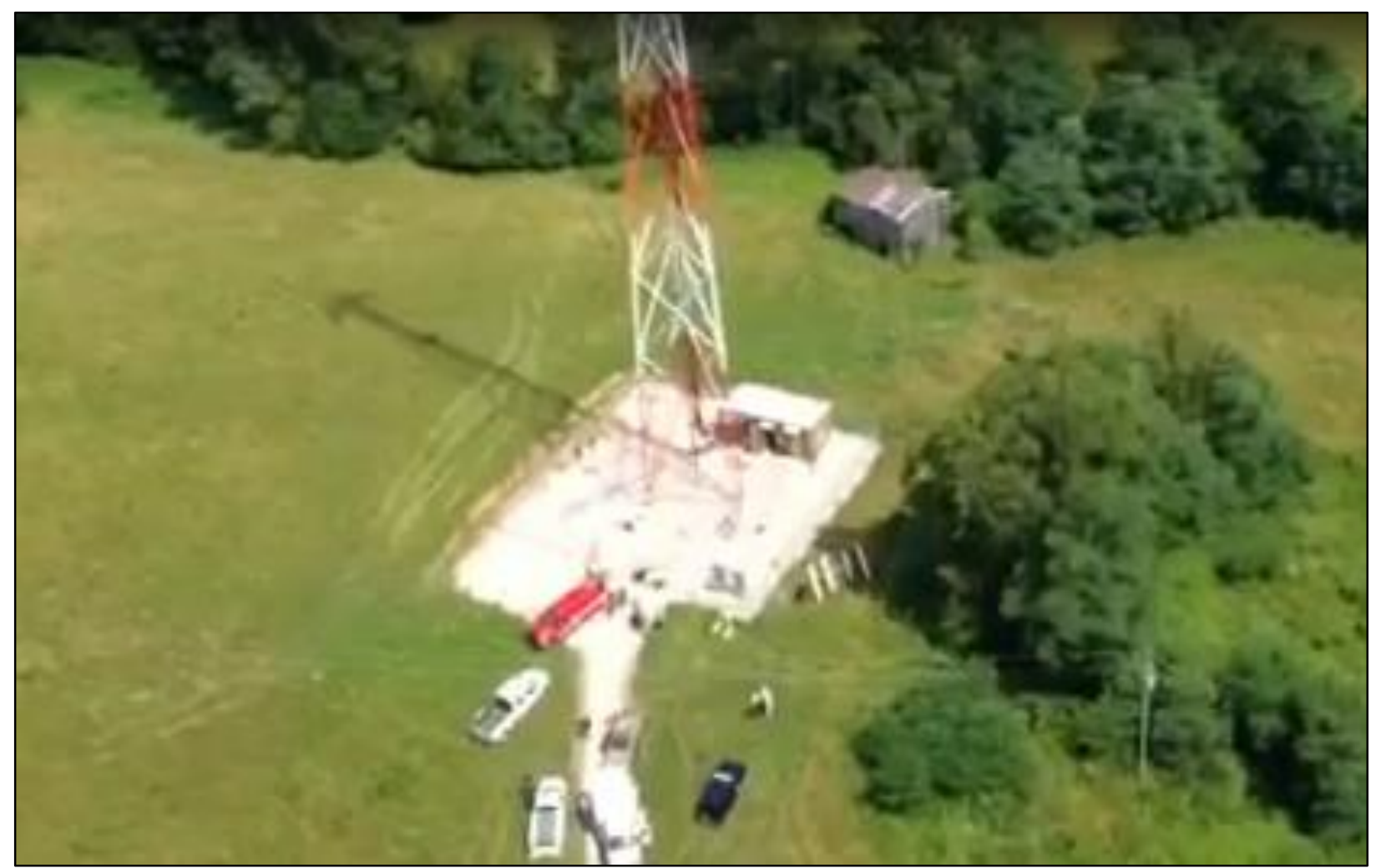

Image 1

Incident scene

Photo courtesy of KY OSHA 


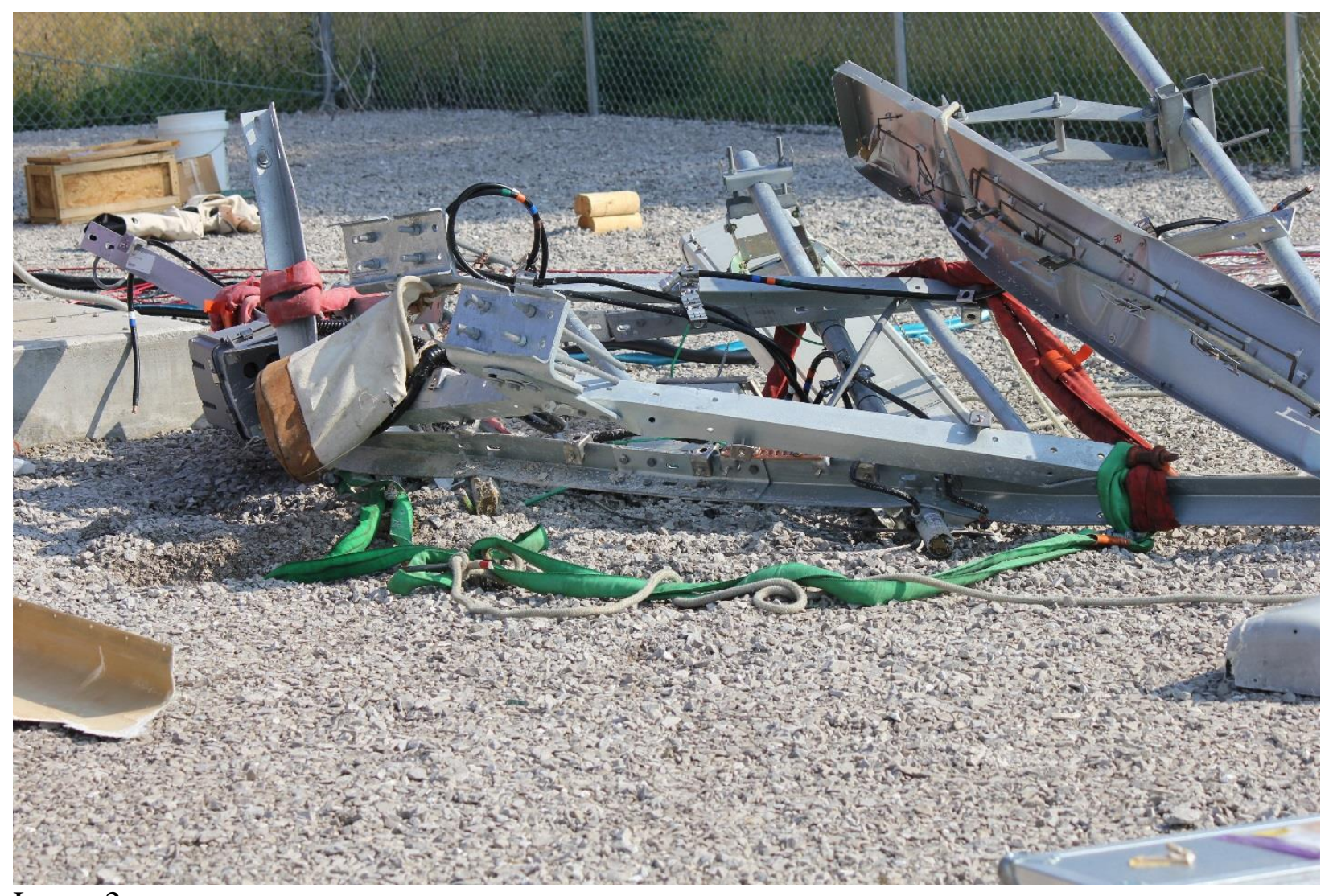

Image 2

Antenna array that fell

Photo courtesy of KY OSHA 

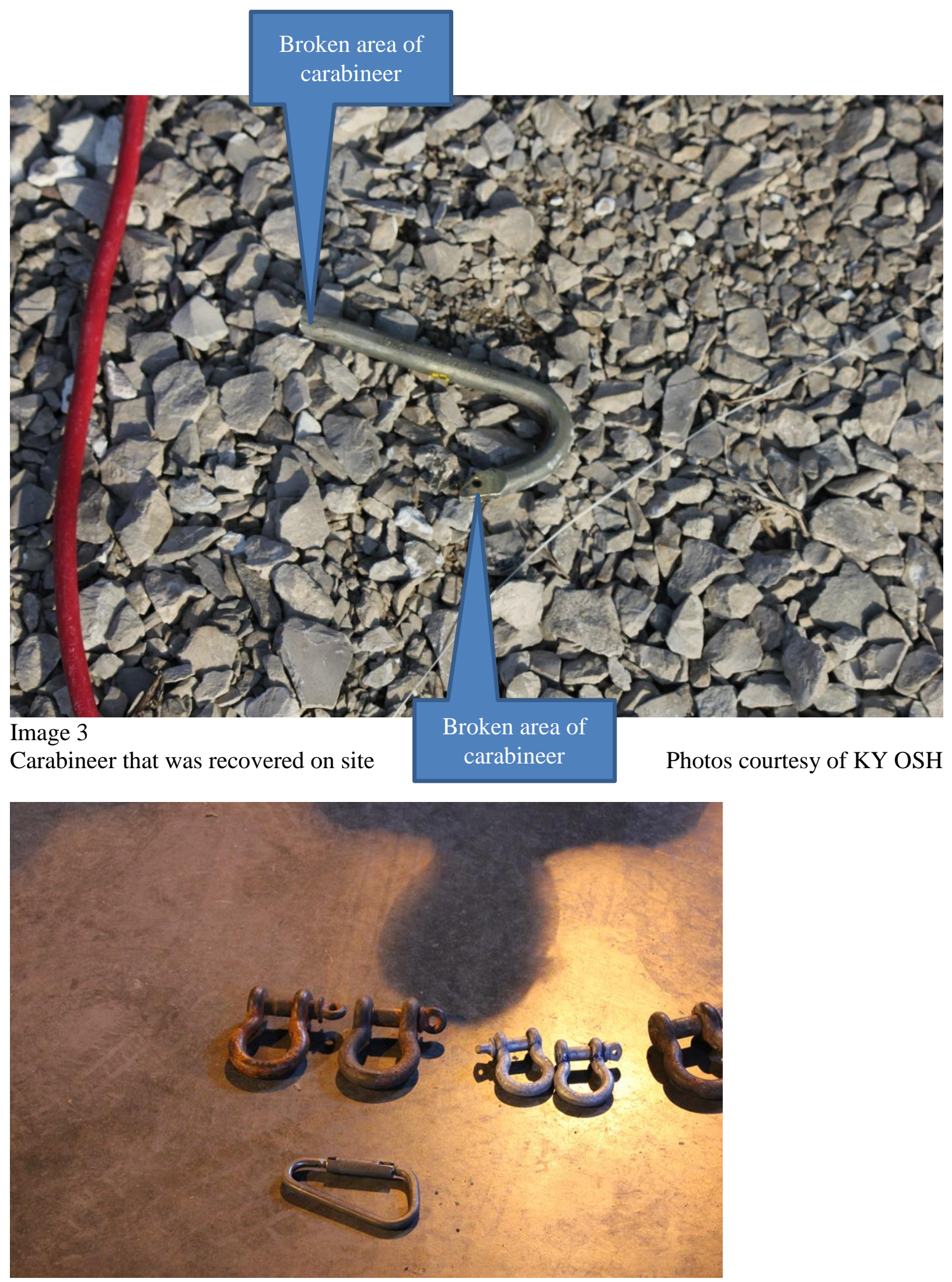

Image 4

Undamaged shackle pins \& carabineer 


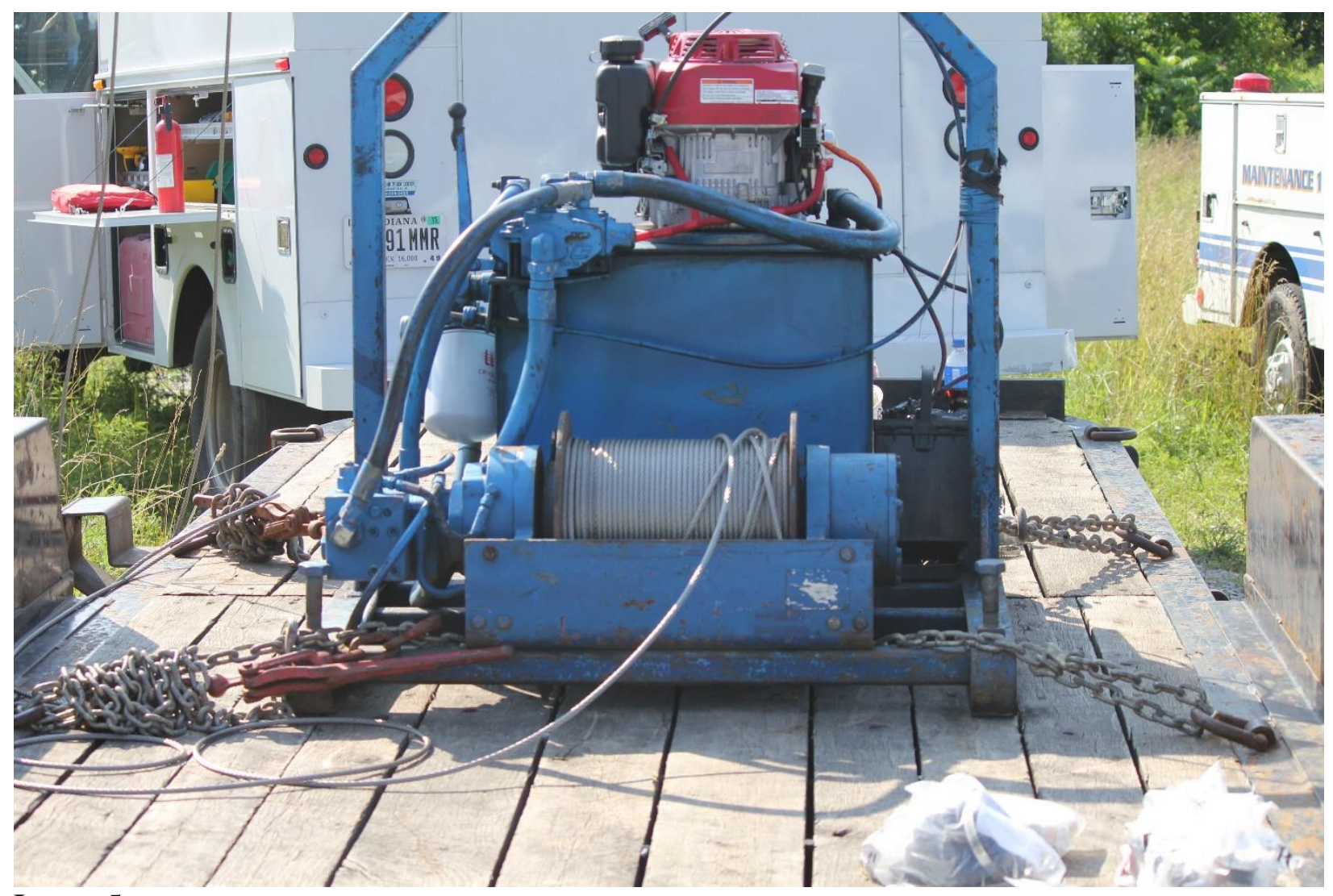

Image 5

Winch that was used

Photo courtesy of KY OSHA 